\title{
EFFECTS OF BISPHENOL A AND LEARNING ON THE DISTRIBUTION OF GABA RECEPTORS IN THE RAT HIPPOCAMPUS AND PREFRONTAL CORTEX
}

\author{
Received November 24, 2013.
}

\begin{abstract}
Bisphenol-A (BPA) is a widely distributed chemical having mixed estrogen agonist/antagonist properties. We investigated the effects of introduction of BPA and passive avoidance learning on the distribution of $\mathrm{GABA}_{\mathrm{Aal}}$ receptors in the rat prefrontal cortex and hippocampus. BPA ( 5 and $50 \mathrm{mg} / \mathrm{kg}$-day) was introduced by oral intake for 15 days; learning and memory were tested in a shuttle-box. The distributions of $\mathrm{GABA}_{\mathrm{Aa} 1}$ receptors were investigated by an immunohistochemical procedure. The BPA treatment significantly decreased the density of $\mathrm{GABA}_{\mathrm{Aal}}$ receptors in the prefrontal cortex and hippocampus. The distribution of these receptors was significantly denser in BPA-exposed rats subjected to learning than that in rats without learning. Thus, BPA treatment leads to down-regulation of $\mathrm{GABA}_{\mathrm{Aa} 1}$ receptors in the prefrontal cortex and hippocampus. Learning a passive avoidance reaction provides upregulation of such receptors in these brain structures.
\end{abstract}

Keywords: bisphenol $\mathrm{A}(\mathrm{BPA})$, passive avoidance learning, $\mathrm{GABA}_{\mathrm{A} a 1}$ receptors, prefrontal cortex, hippocampus, male rats.

\section{INTRODUCTION}

At present, there are alarming reports regarding the reproduction and health hazards of endocrine disrupting chemicals in the environment [1]. Bisphenol A (BPA) is considered one of the most common endocrine disruptors [2]. This compound is extensively used in synthesis of a few types of plastics and is present in a number of products used in industry and everyday life. The molecule of BPA has two phenol rings and possesses structural homology with a ring of $\beta$-estradiol; BPA is suspected to bind to estrogen receptors, to mimic estrogenic actions, and to exert significant adverse effects on humans and animals [3].

GABA is a very important inhibitory neurotransmitter throughout the CNS that acts on $\mathrm{GABA}_{\mathrm{A}}, \mathrm{GABA}_{\mathrm{B}}$, and $\mathrm{GABA}_{\mathrm{C}}$ receptors. GABA receptors mainly mediate fast inhibitory synaptic transmission in the entire brain; this is why these receptors are major targets for many pharmacological agents, in particular synthetic and endogenous steroids [4].

As was reported, in vitro GABA release in medial hyperstriatum ventral slices of the chick

${ }^{1}$ Department of Physiology, School of Veterinary Medicine, Shiraz University, Shiraz, Iran.

Correspondence should be addressed to M. Taherianfard

(e-mail: taherian@shirazu.ac.ir). brain increased following training [5]. The affinity of $\mathrm{GABA}_{\mathrm{A}}$ receptors in different brain regions demonstrates rather significant specificity. Using molecular biological techniques allowed researchers to reveal that a single amino acid residue is responsible for such profound difference in the affinity and functions of these receptors. The presence of a histidine residue at position 101 of the primary amino acid sequence of the $\alpha$ subunit produces subunit $\alpha 1$ characterized by high-affinity binding to diazepam [6]. $\mathrm{GABA}_{\mathrm{A}}$ receptors containing $\alpha 1$ subunit are specific for fast synaptic inhibition in hippocampal $C A 1$ pyramidal cells [7]. These ( $\alpha 1$ subunit-containing) $\mathrm{GABA}_{\mathrm{A}}$ receptors play an important role in modulation of memory acquisition [8]. Some studies indicated the presence of $\mathrm{GABA}_{\mathrm{A}}$ receptors in brain regions such as the prefrontal cortex and hippocampus, i.e., the regions especially important for learning and memory $[9,10]$.

Choi et al. [11] reported that BPA can significantly influence $\mathrm{GABA}_{\mathrm{A}}$ receptors. However, BPA is not likely to act directly on the GABA binding sites of $\mathrm{GABA}_{\mathrm{A}}$ receptors and to open $\mathrm{Cl}^{-}$channels; it did not induce any $\mathrm{GABA}_{\mathrm{A}}$ receptor-mediated currents in dorsal root ganglion neurons where functional GABA receptors are expressed. Instead, BPA might bind to some modulatory sites located in the vicinity of $\mathrm{GABA}_{\mathrm{A}}$ receptor- $\mathrm{Cl}^{-}$channel complexes and in such a 
way affect the GABA receptor function [11].

There are many publications on the effects of $\mathrm{GABA}_{\mathrm{A}}$ receptor agonists and antagonists on the learning process in all technical conditions. There are, however, few studies on the influence of learning on the distribution of $\mathrm{GABA}_{\mathrm{A}}$ receptors. Xenoestrogens, such as BPA, can modulate learning and memory formation. Several studies showed that exposures to BPA in prenatal/neonatal stages or in adult animals induce significant impairment of learning and memory $[1,11,12]$. At the same time, the effect of BPA on $\mathrm{GABA}_{\mathrm{A}}$ receptor distribution in certain brain areas has not been examined until now. The aim of our study was to investigate the interaction of BPA treatment with the effect of passive avoidance learning on the distribution of $\mathrm{GABA}_{\mathrm{A} \alpha 1}$ receptors in the prefrontal cortex and $C A 1$ region of the hippocampus in rats.

\section{METHODS}

Thirty male Sprague-Dawley rats weighing 200-220 g were used. The animals were housed under a $12 / 12 \mathrm{~h}$ light/dark cycle (light on at 6 a.m.) and controlled temperature $\left(20 \pm 4^{\circ} \mathrm{C}\right)$ conditions. Food and water were available ad libitum.

The rats were randomly divided into six equal groups $(n=5$ in each). Three groups were not subjected to avoidance learning. Among them, group 1 received the solvent (sesame oil), while groups 2 and 3 were treated with 5 and $50 \mathrm{mg} / \mathrm{kg} \times$ day BPA, respectively; BPA and sesame oil were applied by oral gavages for 15 days [12]. BPA was purchased from Sigma-Aldrich (USA) and dissolved in sesame oil. Groups 4-6 were trained in the shuttle box and also received pure sesame oil or BPA dissolved in oil ( 5 and $50 \mathrm{mg} / \mathrm{kg} \times$ day, respectively). The learning test was done after 15 days of oral gavages.

Shuttle Box. A two-way shuttle-box with acrylic walls and steel floor bars was used. The box, $44 \times 20 \times 19$ $\mathrm{cm}$, was bisected by a vertical partition into light and dark compartments. The partition had an opening in its middle, which allowed the animal to move freely from one compartment to another. In the light compartment, the animal was safe, while in the dark compartment it could receive a 1 -sec-long foot shock $(0.6 \mathrm{~mA})$ with a latent period of $1.0 \mathrm{sec}$.

Behavioral Procedure. On the first day, all animals were individually subjected to 2-min-long adaptation to the shuttle box, in which the rat could explore the light compartment and was allowed to move about freely. Within this stage, the rats preferred the dark compartment. If the rat did not move to this compartment in $120 \mathrm{sec}$, it was removed from the study. This adaptation was repeated $30 \mathrm{~min}$ later. On the second day, the rats were placed in the light compartment of the box and, $1.0 \mathrm{sec}$ after entering the dark compartment, received a $0.6 \mathrm{~mA}$ foot shock. The latency of coming to the light compartment demonstrated by the rat this day was considered an initial latency. On the third day, the procedure was similar to that on the second day; this day was considered a learning day. On the fourth day (memory consolidation), the procedure was similar to that on the learning day but without a foot shock. On the fifth day (memory retention), the procedure was similar to that on the fourth day. The rats were considered completely learned if they did not move to the dark compartment within a $120 \mathrm{sec}$ interval during the third, fourth, and fifth days of the experiment.

Tissue Preparation. In all groups, the rats were anesthetized by sodium thiopental $(120 \mathrm{mg} / \mathrm{kg})$; after transcardial perfusion with $10 \%$ formaldehyde, their brains were removed, washed by normal saline, and fixed for $72 \mathrm{~h}$ in $10 \%$ formaldehyde in $0.1 \mathrm{M}$ phosphate buffer (PB, pH 7.4). Then, the brains were postfixed in $4 \%$ formaldehyde in $0.1 \mathrm{M} \mathrm{PB}$. After paraffin embeding, paraffin blocks were prepared. Five- $\mu \mathrm{m}-$ thick sections were made and mounted on $25 \%$ L-lysine-coated glass slides.

Immunohistochemical Study. The slide-mounted sections were dried and subsequently stored in a $-20^{\circ} \mathrm{C}$ freezer until used for antibody labeling. After taken from the freezer, these sections of the rat brain were brought to room temperature, washed, and the necessary areas of the section were outlined with a liquidrepellent slide marker pen (to retain reagents on the sections during the immunostaining procedure). The sections were incubated overnight with primary antibodies $(99 \%$ preferring $\alpha 1)$ against $\mathrm{GABA}_{\mathrm{A \alpha} 1}$ receptors $\left(10^{-3}\right.$ dilution $)$. On the next day, the sections were rinsed in PBS, incubated with secondary antibody (envision), and washed in PBS. Finally, the sections were rinsed in PBS three times for 10 min, reacted with a cromogen (Dab), and, after rinsing in PBS, put in a hemotoxilin solution for nucleus staining. Negativecontrol sections were incubated with PBS in the absence of primary antibody, and no immunoreactivity was detected. Figure 1 shows such negative control, where there was no brown color due to the reaction to primary antibody. After preparing digital images of the slides, the distribution of $\mathrm{GABA}_{\mathrm{A} \alpha 1}$ receptor was ana- 


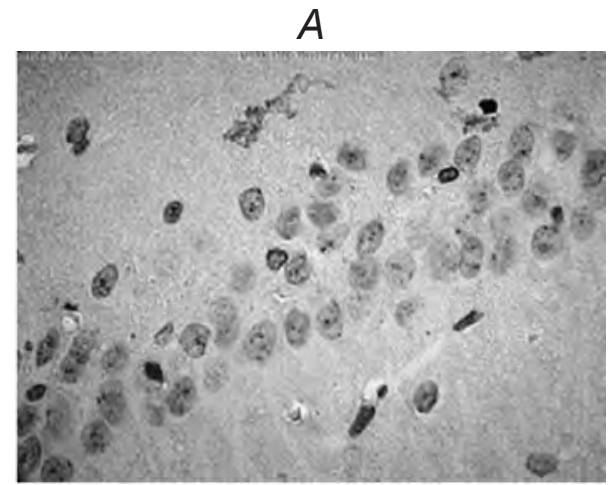

$B$

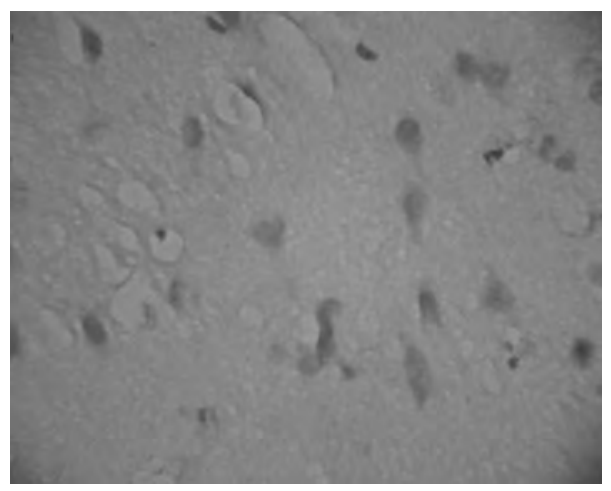

F i g. 1. Photomicrographs of the negative control. A) Hippocampus; B) prefrontal cortex. $\times 400$.

Р и с. 1. Мікрофотографії негативного контролю.

lyzed using Image Analyzer (version 1.33). Three indices characterizing the distribution of receptors (hue, saturation, and intensity) were estimated. It should be taken into account that the above indices (measured by the program in pixels, i.e., arbitrary units) are reverse values, meaning that the greater values of the indices measured, the lower densities of GABA receptors, .

Statistical Analysis. Statistical analyses of the numerical data were performed using SPSS (version 18). One-way ANOVA was used to evaluate betweengroup differences. The data are shown below as mean \pm s.e.m., and the differences were considered significant at $P<0.05$.

\section{RESULTS}

The treatment with BPA in doses of 5 and $50 \mathrm{mg} / \mathrm{kg} \cdot$ day during 15 days with no learning significantly decreased the density of immunoreactive $\mathrm{GABA}_{\mathrm{A \alpha} 1}$ receptors in the prefrontal cortex and hippocampal $C A 1$ region in comparison with the sham group without learning (Figs. 2-5). The indices of color intensity (i.e., the

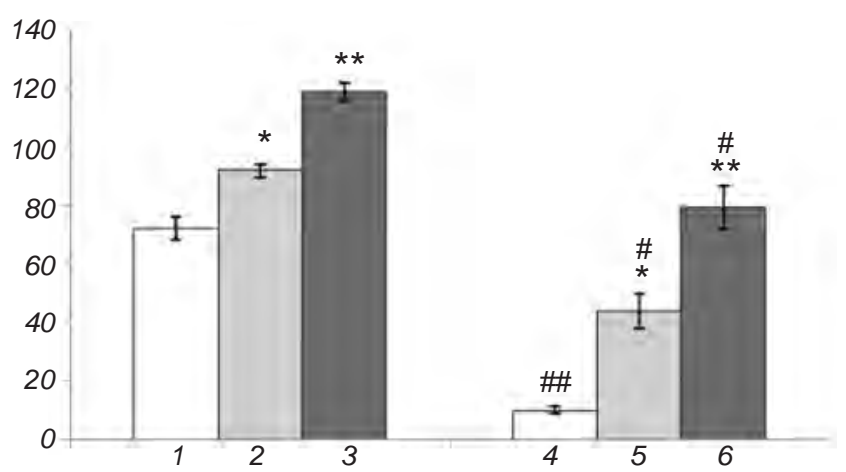

F i g. 2. Effects of BPA and avoidance learning on the GABA receptor distribution in the prefrontal cortex of male rats. Vertical scale) Color intensity, arbitrary units (pixels). 1-6) Experimental animal groups; 1-3, without learning, 4-6, with learning. 1 and 4) Sham groups; 2 and 5) treated with $5 \mathrm{mg} / \mathrm{kg} \cdot$ day BPA; 3 and 6) treated with $50 \mathrm{mg} / \mathrm{kg}$-day BPA. It should be taken into account that the measured index of color intensity is reverse with respect to the density of $\mathrm{GABA}_{\mathrm{Aal}}$ receptors (the greater index, the smaller number of the receptors). One and two asterisks show significant differences from sham groups with $P<0.05$ and $P<0.01$. One and two crosses show the analogous differences between groups 3 vs. 2 and 6 vs. 5. One and two \# signs show significant differences in comparing groups 4 vs. 1,5 vs. 2 , and 6 vs. 3 .

P и с. 2. Впливи бісфенолу А (ВРА) та навчання реакції уникання на розподіл ГАМК ${ }_{\text {А } 1}$-рецепторів у префронтальній корі самців щурів.

reverse values) in slices of the prefrontal cortex in the respective animal groups (2 and 3 ) were significantly greater than the respective index in group 1 $(P<0.05$ and $P<0.01)$. The situation in slices of the hippocampus of the animals with no learning was nearly the same (Fig. 4).

The density of $\mathrm{GABA}_{\mathrm{A} \alpha 1}$ receptors in the prefrontal cortex and hippocampus of animals subjected to successful avoidance learning (groups 4-6) demonstrated the regularities rather similar to those in groups with no learning (1-3). The densities of these receptors after BPA treatment were noticeably smaller than those in the sham learned group. At the same time, all these characteristics were, in general, noticeably greater than those in the respective groups but with no learning.

The indices of color intensity in slices of the prefrontal cortex of BPA-treated groups 5 and 6 were significantly greater $(P<0.05$ and $P<0.01)$ than that in group 4 (i.e., the number of $\mathrm{GABA}_{\mathrm{Aal}}$ receptors was smaller). At the same time, comparisons of groups 4 vs. 1,5 vs. 2 , and 6 vs. 3 showed that the above indices in the learned groups (4-6) were significantly smaller than in groups without learning $(1-3 ; P<$ 
$A$

1

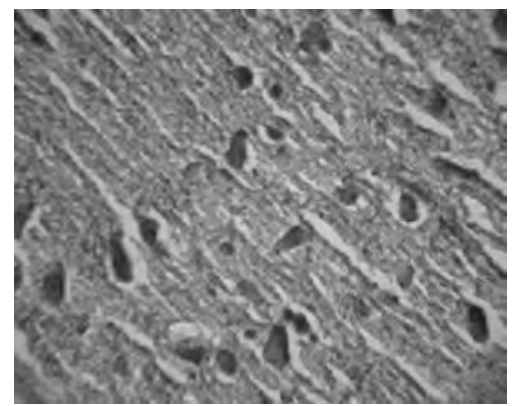

2
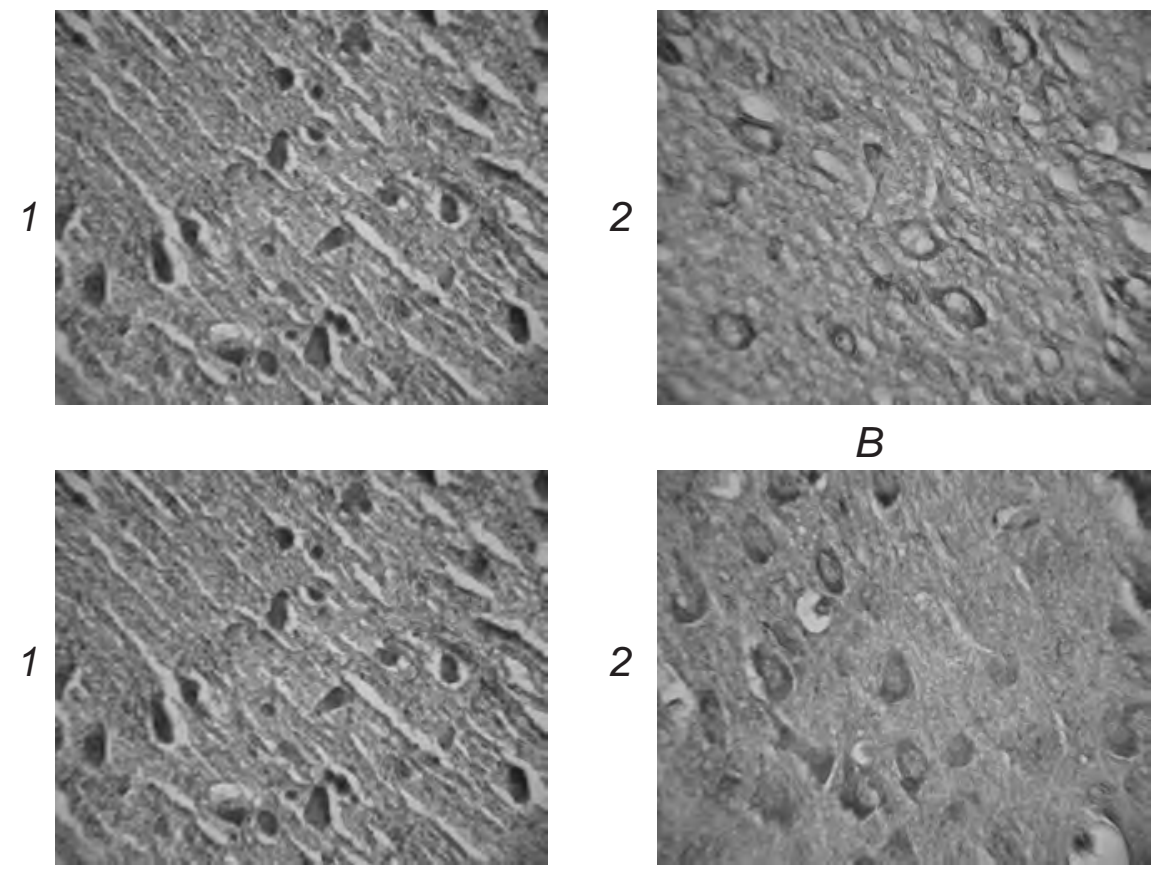

Sham
$B$

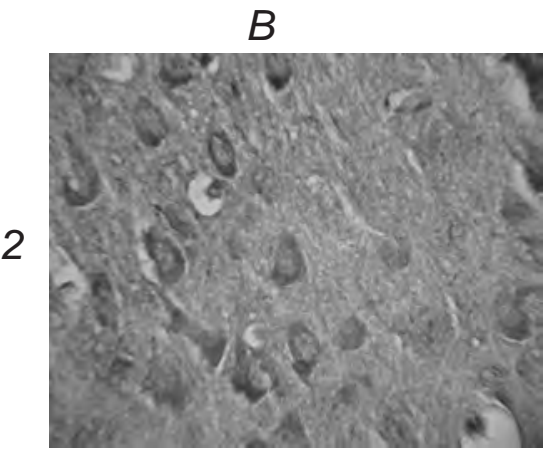

BPA (5 mg/kg.day)
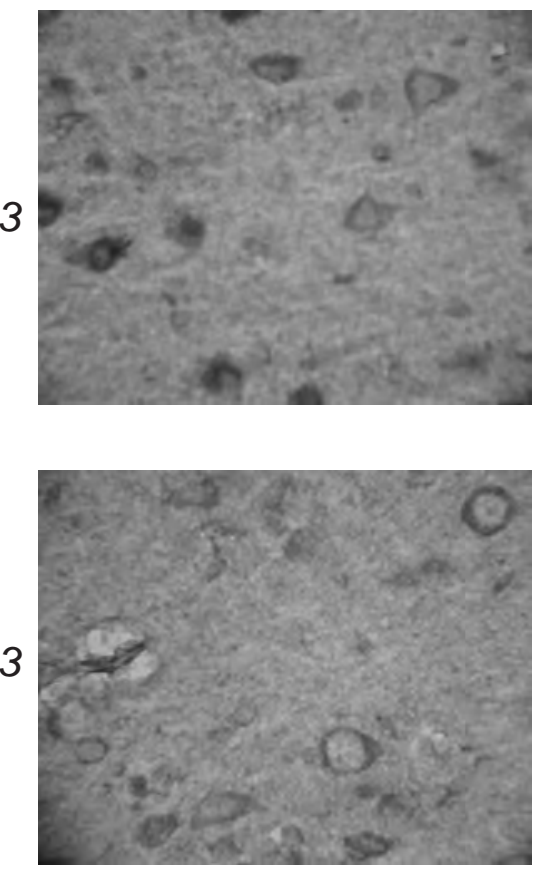

BPA (50 mg/kg.day)

F i g. 3. Photomicrographs of immunostaining of $\mathrm{GABA}_{\mathrm{A \alpha} 1}$ receptors in the prefrontal cortex of rats of the experimental groups without learning (A) and with learning (B). 1) Sham groups; 2) BPA, $5 \mathrm{mg} / \mathrm{kg} \cdot \mathrm{day}$, and 3) BPA, $50 \mathrm{mg} / \mathrm{kg} \cdot \mathrm{day} . \times 400$.

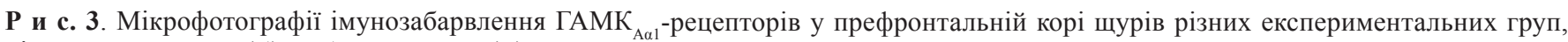
підданих навчанню $(A)$ та без навчання $(B)$.

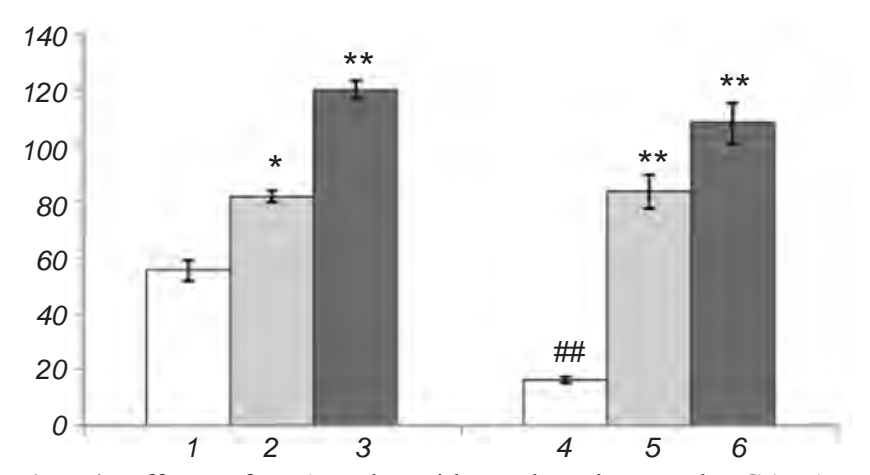

F i g. 4. Effects of BPA and avoidance learning on the $\mathrm{GABA}_{\mathrm{A \alpha} 1}$ receptor distribution in the $C A 1$ region of the hippocampus. Designations are the same as in Fig. 2.

Р и с. 4. Впливи бісфенолу А (ВРА) та навчання реакції уникання

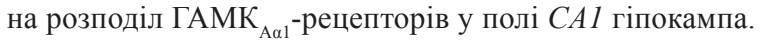

$0.01, P<0.01$, and $P<0.05$, respectively). The pattern of the corresponding differences for the hippocampus was rather similar, but in this case the differences for groups 5 vs. 2 and 6 vs. 3 did not reach the significance level.

Therefore, the treatment with BPA induces downregulation of $\mathrm{GABA}_{\mathrm{A} \alpha 1}$ receptors in the prefrontal cortex and hippocampus of male rats, while learning passive avoidance leads to up-regulation of these receptors in the above-mentioned brain structures. A combination of BPA treatment and avoidance learning leads to down-regulation of $\mathrm{GABA}_{\mathrm{A \alpha 1}}$ receptors in the prefrontal cortex and $\mathrm{CA} 1$ region of hippocampus, but the effect is more moderate than that in animals without learning.

\section{DISCUSSION}

Previous studies were focused on the estrogenic action of BPA; so, the main effect of BPA was considered related to its action on reproductive tissues [13]. Nonetheless, in addition to the effects on the above tissues, BPA is likely to significantly alter morphological and functional properties of neuronal cells in the CNS. In particular, BPA was shown to inhibit estradiol-induced hippocampal synaptogenesis [14].

In our study, BPA decreased the number of immunoreactive $\mathrm{GABA}_{\mathrm{A} \alpha 1}$ receptors in the prefrontal cortex and $C A 1$ hippocampus region in the rat brain. 
1

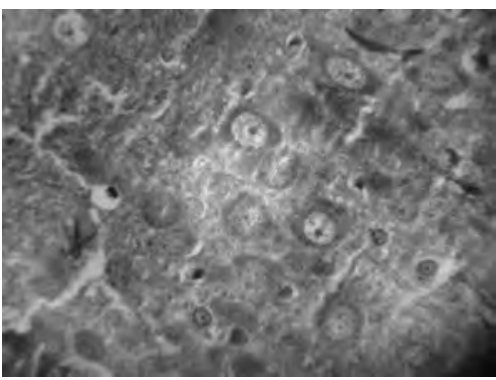

1

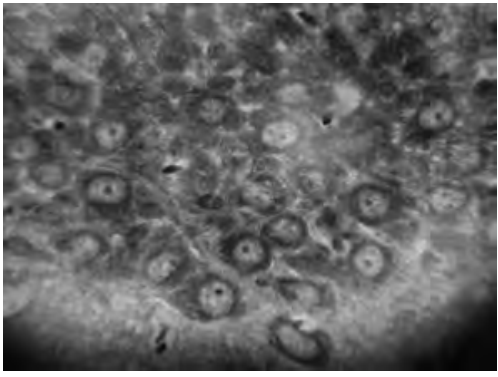

2

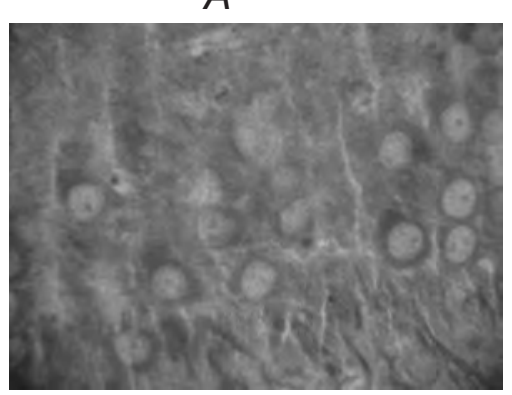

$B$

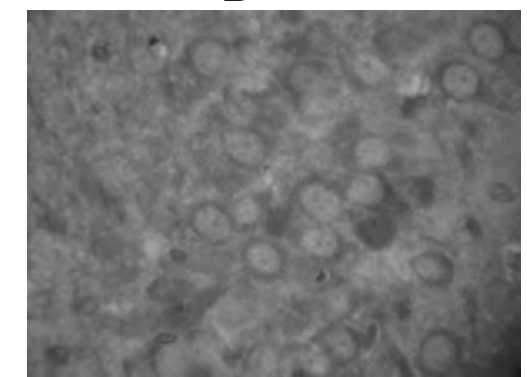

3

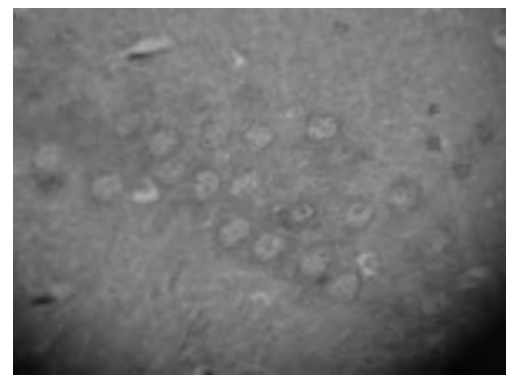

3

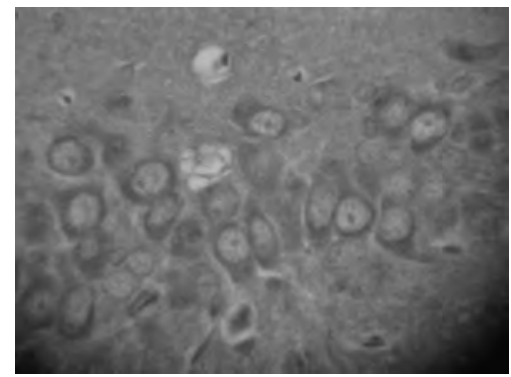

F i g. 5. Photomicrographs of immunostaining of $\mathrm{GABA}_{\mathrm{A} \alpha 1}$ receptors in the $C A 1$ hippocampal region of rats of different experimental groups. Designations are similar to those in Fig. 3.

Р и с. 5. Мікрофотографії імунозабарвлення ГАМК Аа1 - рецепторів у полі $C A 1$ гіпокампа щурів різних експериментальних груп.

Aoshima et al. [15] reported that BPA exerted complex effects on $\mathrm{GABA}_{\mathrm{A}}$ receptor-mediated responses. This agent in low amounts potentiated the responses in the presence of GABA low concentrations, while high concentrations of BPA inhibited such reactions. Neurosteroids can affect gene expression of $\mathrm{GABA}_{\mathrm{A}}$ receptor subunits, modifying, in such a way, $\mathrm{GABA}_{\mathrm{A}}$ receptor distribution [16]. Progesterone and $3 \alpha-\mathrm{OH}-5 \alpha$ pregnan-20-one decreased the $\alpha 1$ subunit mRNA levels in the $C A 2, C A 3$ subfields, and dentate gyrus of the hippocampus in animals pretreated with estradiol [16].

Akk et al. [17] reported that agonistic effects of neurosteroids on $\mathrm{GABA}_{\mathrm{A}}$ receptors depend on an open vs. closed state of $\mathrm{GABA}_{\mathrm{A}}$ receptors. Neurosteroids, in particular $(3 \alpha, 5 \alpha, 17 \beta)-3-\mathrm{OH}-18$-norendrostane, increased the $\mathrm{GABA}_{\mathrm{A}}$ receptor number in the case of the open state of these receptors but decreased this value in the closed state of such receptors. According to our results, it seems that BPA manifests antagonistic effects with respect to neurosteroids, since exposure to this agent decreases the $\mathrm{GABA}_{\mathrm{A}}$ receptor density in the rat prefrontal cortex and $C A 1$ hippocampal region. BPA having two hydroxyl residues provides only noncompetitive inhibition of $\mathrm{GABA}_{\mathrm{A}}$ receptors composed of $\alpha 1$ and $\beta 1$ subunits [15]. As was mentioned above, exposure to BPA decreases the number of $\mathrm{GABA}_{\mathrm{A} \alpha 1}$ receptors in the cerebral structures examined.
As our experiments demonstrated, BPA in both doses significantly decreased the density of these receptors, but the respective decreases were noticeably lower in the groups trained for the avoidance reaction. The corresponding effects of BPA treatment combined with learning are rather similar in the prefrontal cortex and hippocampus but, at the same time, such effects demonstrate some specificity.

Several studies in humans and rodents demonstrated that the prefrontal and cingulate cortices, hippocampus, striatum, amygdalar complex, and thalamus are involved in the formation of depressionlike behaviors [18-20]. Shifts in the GABA system in these brain structures are probably significantly responsible for such behavioral modifications [19]. There are strains of mice that posses an amino acid mutation in specific transmembrane regions of $\mathrm{GABA}_{\mathrm{A}}$ receptors having $\alpha 1$ subunits $[21,22]$. Berry et al. [23] demonstrated that mice with the GABA $\mathrm{A}_{\mathrm{A}}$ receptor $\alpha 1$ subunit mutation swim less intensely in both spatial and nonspatial Morris water maze tests, compared to the control. Overall, it appears that $\alpha 1$ subunits of $\mathrm{GABA}_{\mathrm{A}}$ receptors may play a crucial role in the performance of the above types of tests in mice. Stagg et al. [24] found that the responsiveness of the GABA system to modulation strongly correlates with motor learning, and this is suggestive for a possible relevance 
of GABA to LTP-like synaptic plasticity in motor learning of humans. Zheng et al. [25] demonstrated that both protein and mRNA of the $\mathrm{GABA}_{\mathrm{A}}$ receptor $\alpha 1$ subunit in the hippocampus and prefrontal cortex were affected by acute restraint stress. These authors suggested that $\mathrm{GABA}_{\mathrm{A}}$ receptors could play a considerable role in the regulation of learning and memory. Lech et al. [26] showed that the GABA receptor $\alpha 1$ subunit is upregulated in the locus of cortical layer IV underwent to learning-induced plastic changes. This subunit of $\mathrm{GABA}_{\mathrm{A}}$ receptors reacts with a delay to the process occurring in the cortex during plasticity modifications induced by associative learning, since the changes in mRNA expression do not appear during or immediately after the training period. Several studies showed that treatment with BPA impaired learning and memory in different tests. According to the results of our study, it seems that learning and memory impairment induced by exposure to BPA may be induced by changes in the $\mathrm{GABA}_{\mathrm{A} \alpha 1}$ receptor expression and distribution in crucial brain areas (such as the $C A 1$ region of the hippocampus and prefrontal cortex).

Acknowledgments. This study was financially supported by the Iran National Science Foundation (INSF).

The authors are thankful to Dr. S. Dehghani Najvani, Professor of the Shiraz University, for valuable assistance in the preparation of the manuscript.

The study was carried out in accordance with the statements of the Council Directive regarding the protection of animals used for experimental and other scientific purposes $(86 / 609 /$ EEC, 1986, Strasbourg) and respective regulations of the Ethics Committee of the Shiraz University.

The authors, M. Taherianfard and A. A. Taci, confirm that the research and publication of the results were not associated with any conflicts regarding commercial or financial relations, relations with organizations and/or individuals who may have been related to the study, and interrelations of co-authors of the article.

\section{M. Тахеріанфард ${ }^{1}$, A. A. Taci ${ }^{1}$}

\section{ВПЛИВИ БІСФЕНОЛУ А ТА НАВЧАННЯ УНИКАННЮ} НА РОЗПОДІЛ ГАМК ПРЕФРОНТАЛЬНІЙ КОРІ ЩУРІВ

\footnotetext{
${ }^{1}$ Коледж ветеринарної медицини Шіразького університету (Іран).

P е 3 ю м е
}

Бісфенол А (ВРА) - це широко розповсюджений хімікат, що має змішані властивості агоніста/антагоніста естрогенів.
Ми досліджували впливи введення ВРА та навчання реакції пасивного уникання на розподіл ГАМК фронтальній корі та гіпокампі щурів. ВРА (5 або 50 мг/кг на добу) вводився перорально протягом 15 діб. Результати навчання та формування пам'яті тестували в човниковій камері. Розподіл ГАМК танням імуногістохімічної методики. Введення ВРА істотно

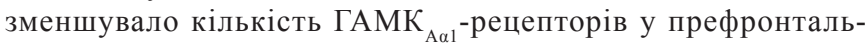
ній корі та полі $C A 1$ гіпокампа. Розподіл цих рецепторів був значно щільнішим у щурів, котрим уводили ВРА та піддавали навчанню, ніж у тварин, яким навчання не проводили. Таким чином, уведення ВРА призводить до негативної регуляції системи ГАМК та гіпокампі, тоді як навчання пасивній реакції уникання забезпечує позитивну регуляцію даної системи в згаданих мозкових структурах.

\section{REFERENCES}

1. K. Miyagawa, M. Narita, H. Akama, and T. Suzuki, "Memory impairment associated with a dysfunction of the hippocampal cholinergic system induced by prenatal and neonatal exposures to bisphenol-A," Neurosci. Lett., 418, No. 3, 236241 (2007). doi:S0304-3940(07)00125-5 [pii] 10.1016/j. neulet.2007.01.088.

2. W. V. Welshons, S. C. Nagel, and F. S. V. Saal, "Large effects from small exposures. III. Endocrine mechanisms mediating Effects of bisphenol a at levels of human exposure," Suppl.: Endocrinol. Endocrine Disrupt. Chem., 147, No. 6, s56-s69 (2006). doi:DOI: 10.1210/en.2005-1159.

3. L. Corrieri, D. D. Seta, C. Virginie, and L. Fusani, "Developmental exposure to xenoestrogen enhances spatial learning in male rats," Horm. Behav., 51, 620-625 (2007). doi:10.1016/j.yhbeh.2007.03.002.

4. P. J. Whiting, "GABA $\mathrm{A}_{\mathrm{A}}$ receptor subtype in the brain: a paradigm for CNS drug discovery?" Drug. Discov., 8, 445-450 (2003).

5. B. J. McCabe, G. Horn, and K. M. Kendrick, "GABA, Taurine and learning: release of amino acids from slices of chick brain following filial imprinting," Neuroscience, 105, No. 2, 317 324 (2001). doi:S0306-4522 (01) 00186-5.

6. H. A. Wieland, H. Lüddens, and P. H. Seeburg, "A single histidine in $\mathrm{GABA}_{\mathrm{A}}$ receptors is essential for benzodiazepine agonist binding," J. Biol. Chem., 267, 1426-1429 (1992).

7. G. A. Prenosil, M. S. Gasser, U. Rudolph, et al., "Specific subtypes of $\mathrm{GABA}_{\mathrm{A}}$ receptors mediate phasic and tonic forms of inhibition in hippocampal pyramidal neurons," J. Neurophysiol., 96, 846-857 (2006).doi:DOI:10.1152/ jn.01199.2006.

8. M. M. Savic, D. I. Obradovic, N. D. Ugresie, et al., "Bidirectional effects of benzodiazepine binding site ligands on passive avoidance task: differential antagonism by flumazenil and beta-CGt," Behav. Brain Res., 158, 293-300 (2005).

9. D. L. Krebs-Kraft, M. G. Wheeler, and M. B. Parent, "The memory-impairing effects of septal GABA receptor activation involve GABAergic septo-hippocampal projection neurons," Learning Memory, 14, 833-841 (2007).doi:10.1101/1m.809407.

10. R. A. Rissman, R. Nocera, L. M. Fuller, et al., "Age-related 
alterations in $\mathrm{GABA}_{\mathrm{A}}$ receptor subunits in the nonhuman primate hippocampus," Brain Res., 1073/1074, 120-130 (2006). doi:DOI: 10.1016/ J.brainres.2005.12.036.

11. I. S. Choi, J. H. Cho, E. J. Park, et al., "Multiple effects of bisphenol A, an endocrine disrupter, on GABA(A) receptors in acutely dissociated rat CA3 pyramidal neurons," Neurosci. Res., 59, No. 1, 8-17 (2007). doi:S0168-0102(07)00179-4 [pii] 10.1016/j.neures.2007.05.003.

12. C. R. Goncalves, R. W. Cunha, and D. M. Barros, "Effect of prenatal and postnatal exposure to a low dose of bisphenol A on behavior and memory in rats," Environ. Toxicol. Pharmacol., 30, 195-201 (2010). doi:DOI:10.1016/j.etap.2010.06.003.

13. C. Gupta, "Reproductive malformation of the male offspring following maternal exposure to estrogenic chemicals," Proc. Natl. Acad. Sci. USA, 92, 7749-7753 (2000). doi:PMID:10806411.

14. N. J. MacLusky, T. Hajszan, and C. Leranth, "The environmental estrogen bisphenol A inhibits estradiolinduced hippocampal synaptogenesis," Environ. Health Perspect., 113, 675-679 (2005). doi:10.1289/ehp.7633.

15. H. Aoshima, S. J. Hossain, H. Imamura, and R. Shingai, "Effects of bisphenol A and its derivatives on the response of GABA(A) receptors expressed in Xenopus oocytes," Biosci. Biotechnol. Biochem., 65, No. 9, 2070-2077 (2001).

16. M. Orchinik, N. G. Weiland, and B. S. McEwen, "Chronic exposure to stress levels of corticosterone alters $\mathrm{GABA}_{\mathrm{A}}$ receptor subunit mRNA levels in rat hippocampus," Mol. Brain Res., 34, No. 1, 29-37 (1995).

17. G. Akk, J. R. Bracamontes, "Neuroactive steroids have multiple actions to potentiate GABA $\mathrm{A}_{\mathrm{A}}$ receptors," J. Physiol., 558, 59-74 (2004). doi:10.1113/jphysiol.2004.066571.

18. K. McFarlane and P. W. Kalivas, "The circuity mediating cocaine-induced reinstatement of drug-seeking behavior," $J$. Neurosci., 21, 8655-8663 (2001).

19. P. Brambilla, J. Perez, F. Barale, et al., "GABAergic dysfunction in mood disorders," Mol. Psychiat., 8, No. 715,
$721-737$ (2003).

20. A. M. Farrar, L. Font, M. Pereira, et al., "Forebrain circuity involved in effort-related choice: injections of the $\mathrm{GABA}_{\mathrm{A}}$ agonist muscimol into ventral pallidum after response allocation in food-seeking behavior," Neuroscience, 152, 321 330 (2008).

21. C. M. Borghese, D. F. Werner, N. Topf, et al., "An isofluraneand alcohol-insensitive mutant $\mathrm{GABA}_{\mathrm{A}}$ receptor $\alpha 1$ subunit with near-normal apparent affinity for GABA: Characterization in heterologous systems and production of knockin mice," J. Pharmacol. Exp. Therapeutic, 319, No. 1, 208-218 (2006). doi:10.1124/ jpet.106.104406.

22. J. M. Sonner, D. F. Werner, F. P. Elsen, et al., "Effect of Isoflurane and other potent inhaled anesthetics on minimum alveolar concentration, learning, and the righting reflex in mice engineered to express $\alpha_{1} \gamma$-aminobutyric acid type A receptors unresponsive to isoflurane," Anesthesiology, 106, No. 1, 107-113 (2007).

23. R. B. Berry, D. F. Werner, X. F. Wang, et al., "Mice with targeted genetic reduction of $\mathrm{GABA}_{\mathrm{A}}$ receptor al subunits display performance differences in Morris water maze tasks," Neurobiol. Learn Mem., 90, 580-583 (2008). doi:10.1016/j.nlm.2008.06.004.

24. C. J. Stagg, V. Bachtiar, and H. Johansen-Berg, "The role of GABA in human motor learning," Curr. Biol., 21, 480-484 (2011). doi:DOI: 10.1016/j.cub.2011.01.069

25. G. Zheng, X. Zhang, Y. Chen, et al., "Evidence for a role of $\mathrm{GABA}_{\mathrm{A}}$ receptor in the acute resraint stress-induced enhancement of spatial memory," Brain Res., 1181, 61-73 (2007). doi:DOI: 10.1016/j.brainres.2007.08.077.

26. M. Lech, A. Skibinska, and M. Kossut, "Delayed upregulation of $\mathrm{GABA}_{\mathrm{A}}$ alpha1 receptor subunit mRNA in somatosensory cortex of mice following learning-dependent plasticity of cortical representations," Mol. Brain Res., 96, 82-86 (2001). doi:10.1016/S0169-328X(01)00271-6. 